\title{
The Use of Geothermal Energy at Large Scales and Its Benefits over Other Sources of Renewable Energy
}

\section{Dr. Fazil T. Najafi, University of Florida}

\author{
Dr. Fazil T. Najafi
}

For many years, Dr. Fazil T. Najafi has worked in government, industry and education. He earned a BS, MS and PhD degrees from Virginia Polytechnic Institute and State University, Blacksburg, Virginia. His experience in industry includes work as a highway, structural, mechanical, and consultant engineer and construction manager for government and private companies. Najafi taught for many years at Villanova University, Pennsylvania, a visiting professor at George Mason University, and then to the University of Florida, Department of Civil and Coastal Engineering, where he is currently a professor in the Engineering School of Sustainable Infrastructure and Environment, Department of Civil and Coastal Engineering. He has received numerous awards including Fulbright cholarship awards, teaching awards, best paper awards, community service awards, and admission as an Eminent Engineer into Tau Beta Pi. His research on passive radon-resistant new residential building construction was adapted in HB1647 building code of Florida Legislature. Najafi is a member of numerous professional societies and has served on many committees and programs, and continuously attends and presents refereed papers at international, national, and local professional meetings and conferences. Lastly, Najafi attends courses, seminars and workshops, and has developed courses, videos and software packages during his career. His areas of specialization include transportation planning and management, legal aspects, construction contract administration, public works and renewable energy.

\section{Ms. Emily Rivera P.E., University of Florida}

Emily Rivera is a Civil Engineer with the US Army Corps of Engineers at the Washington Aqueduct in Washington, DC. She holds a BS Degree from the University of Puerto Rico, Mayaguez Campus and is pursuing a Master's Degree in Water Resources Planning and Management at the University of Florida.

\section{Ryan Thrun, U.S. Navy}

Ryan Thrun, P.E., LEED AP BD+C

Ryan Thrun is a Civil Engineer with the U.S. Navy Civil Engineer Corps. Thrun graduated from the University of Florida in 2005 with a Bachelor of Science in Civil Engineering before being commissioned as a Naval Officer later that year. He has been stationed at various military bases along the east coast and Afghanistan primarily managing large-scale construction projects. He has obtained his professional registration and LEED accreditation while stationed in Maryland. Thrun is currently pursuing a Master's of Engineering degree at the University of Florida before relocating to Guantanamo Bay, Cuba as the Facilities Engineering and Acquisition Division Director for the base. His areas of specialization include construction management, public works, and government acquisition \& contract management.

\section{Ms. Sarah Isabel Romero, University of Florida}

Currently a graduate student at University of Florida achieving a Masters in Environmental Engineering Sciences. 


\title{
THE LARGE SCALE USE OF GEOTHERMAL ENERGY AND ITS BENEFITS OVER OTHER SOURCES OF RENEWABLE ENERGY.
}

\begin{abstract}
As climate change becomes more of a reality, and as our non-renewable resources are becoming depleted, finding "cleaner" renewable energy for our society is imperative. In recognition of this problem, the objective of this paper is to present the geothermal energy as one of the clean and sustainable form of renewable energy that uses the heat stored in the Earth as its source of energy. Its first commercial uses dates back to the early 1800's and has continued to grow throughout the years. One of its most known and common uses is at a small scale as a heat source for residences. It can also be used at a much larger scales. There are several questions that come up with large scale geothermal energy model. How much energy can be produced? Can geothermal energy produce enough energy for a whole town, city, or country? What is the initial cost and lifelong cost of geothermal energy? Are there limitations in regards to geographic locations? This paper will identify and explore the viability of different large-scale uses of geothermal energy, and how it stands out in comparison to other major sources of renewable energy such as wind power, solar power, hydropower and bio energy. The results of this study indicates initial costs of geothermal power plants is high, even double compared to other power generation plants, due to the high cost of well drilling and well exploration. However, the lifecycle costs of geothermal plants tend to be much lower, resulting in a sound economic choice over the lifespan of a facility. Particularly when considering the environmental benefits of using geothermal power over traditional forms of fossil power production. This study is related to improvement and enhancement of graduate engineering education in a changing environment. Engineers must recognize the negative impacts of fossil fuel as the main source of energy. And the facts of the price of silence on climate change and the high cost on environment caused by fossil fuel carbon emission. And the recognition in the number of people and property likely to be affected by rising sea levels caused by melting polar ice caps. The study and analysis of geothermal energy as one of the clean and sustainable form of renewable energy would fit the call in the graduate division and it is consistent with the division objective.
\end{abstract}

Keywords: Geothermal, Sustainable Energy, Renewable Energy, Green Energy, Power Production 


\section{INTRODUCTION}

The world is facing a huge problem as it still heavily relies on non-renewable energy resources such as coal, oil, and natural gas. Additionally, the global population keeps on growing and with it, the demand for energy. The United Nations Food and Agriculture Organization predicts that this growth will continue and that in 2050 the population will reach 9 billion. With the current human dependency of non-renewable energy, there will be a shortfall of energy unless alternative sustainable renewable energy is explored and implemented. Furthermore, climate change is becoming more of a reality (1). Finding "cleaner" and renewable energy is imperative.

Geothermal energy is a clean and sustainable form of renewable energy that uses the heat stored in the Earth as its source of energy. Many technologies have been developed to take advantage of geothermal energy. Large scale geothermal, often called hydrothermal, is when heat reservoirs deep below the earth's surface are drilled into, injected with cool water and extracts hot water and/or steam for power production (Figure 1). Small scale geothermal, often called geothermal heat pumps or ground source heat pumps, is where the relatively constant temperature of earth's shallow crust of $50^{\circ}-60^{\circ} \mathrm{F}$ is used to extract or transfer heat in HVAC heat and refrigeration cycles (2).

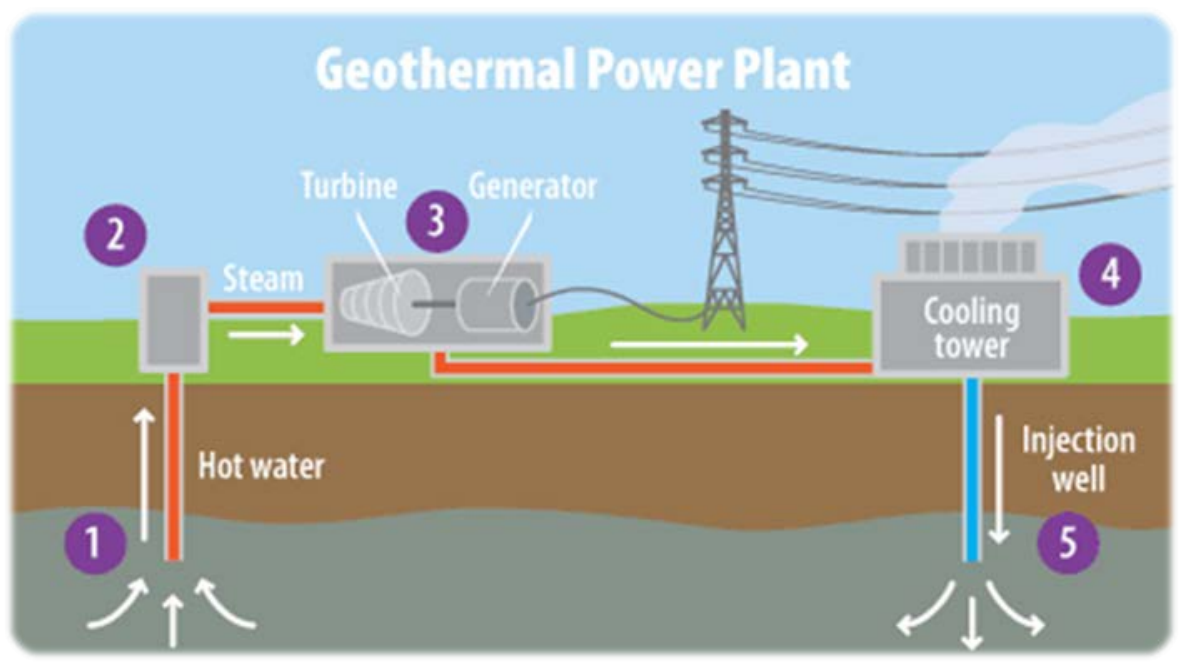

\section{FIGURE 1 Large Scale Geothermal Power Generation Concept}

Geothermal is a great source of energy but is it feasible in today's current high and increasing demand of energy? The following questions are typically presented when initially looking into the large scale geothermal energy model:

- How much energy can be produced?

- Can geothermal energy produce enough energy for a whole town, city, or country?

- What is the initial cost and lifecycle cost of geothermal energy?

- Are there limitations in regards to geographic locations?

This paper will answer these questions and identify the viability of different large-scale uses of geothermal energy, and how it stands out in comparison to other major sources of renewable energy such as wind power and solar power. 
The amount of geothermal power that is able to be produced can be expressed in several different ways, such as how many megawatts of electric power $\left(\mathrm{MW}_{\mathrm{e}}\right)$ a single geothermal well or plant produces, or at a larger scale, such as the total $\mathrm{MW}_{\mathrm{e}}$ or even gigawatts of electric power $\left(\mathrm{GW}_{\mathrm{e}}\right)$ produced by an entire country. Another aspect that must be addressed is the total amount of power that a geographical location is able to produce, also known as its potential, versus what is actually being produced as installed.

\section{Well Production}

At the most microscopic level is the amount of power produced by an individual production well. The first successful geothermal production well in the United States was drilled in 1922 in California at what is known today as the Geysers reservoir (Figure 2). The well was only 200 feet deep and was eventually connected to a 2-well power plant producing $35 \mathrm{~kW}_{\mathrm{e}}$. (3)

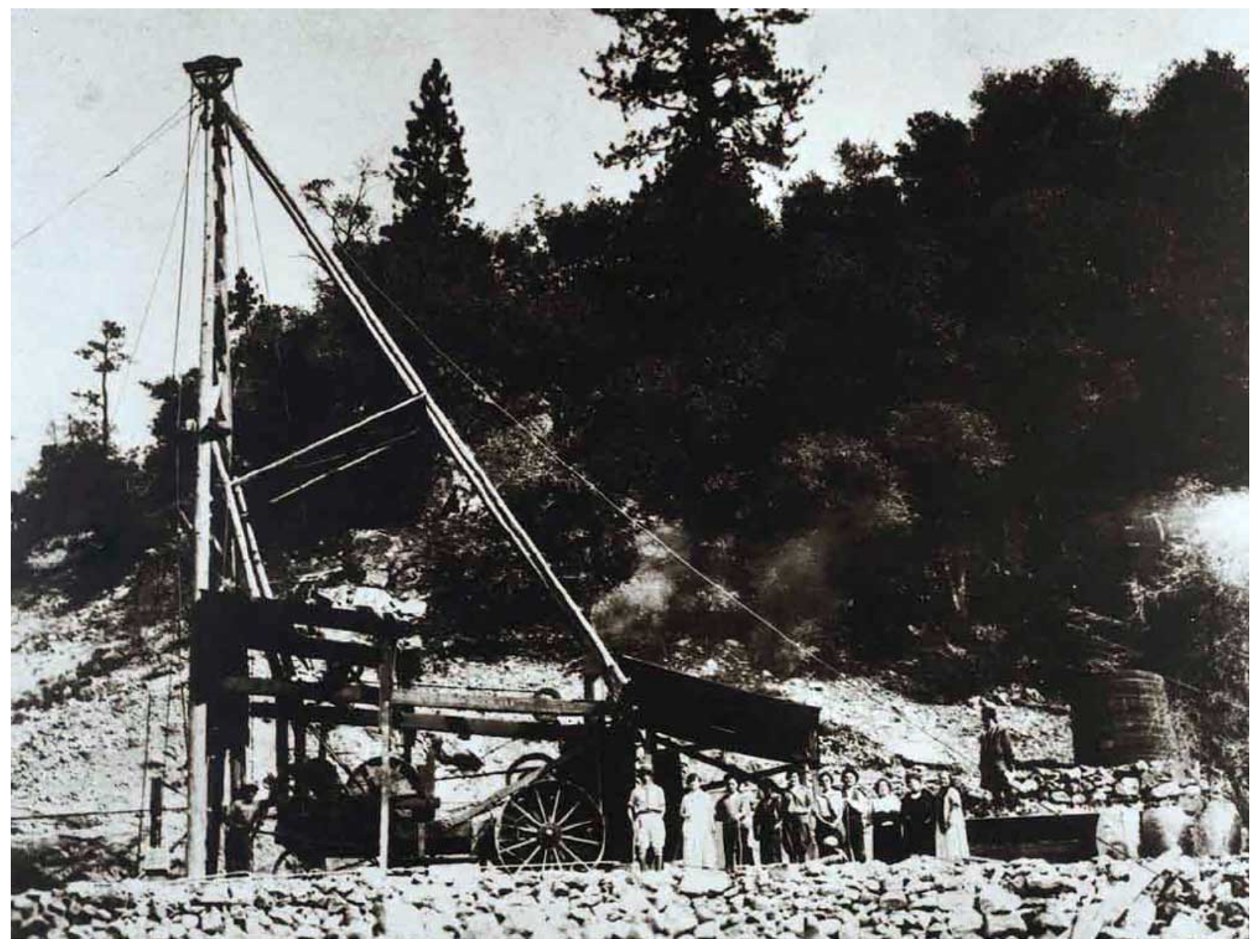

\section{FIGURE 2 First successful geothermal well in the Unites States.}

Well drilling technologies have come a long way since then and wells now are typically drilled 1 to 2 miles below the earth's surface. Based on verified production capacities of over 1,000 operational wells, the average well will produce $6.8 \mathrm{MW}_{\mathrm{e}}$ with a modal average of $3 \mathrm{MW}_{\mathrm{e}}$ (4). This number varies based on well depth and geological formations being drilled into. Some wells are verified as producing up to $52 \mathrm{MW}_{\mathrm{e}}$, but this atypical (4). 


\section{Field Production}

Geothermal fields typically contain multiple geothermal wells drilled at various depths (4). Geothermal fields typically have between 10 and 20 wells (4), although some facilities, such as the Navy Geothermal Plant in Coso, CA, contain over 120 wells across 2 fields (5). The average amount of geothermal power produced per field is approximately $25 \mathrm{MW}_{\mathrm{e}}$ (4). This rages widely, with some plants producing up to $270 \mathrm{MW}_{\mathrm{e}}$ like the Navy Geothermal Plant (5), and others as little as $250 \mathrm{~kW}_{\mathrm{e}}$, like the geothermal plant at University of North Dakota (6).

\section{Plant/Complex Production}

Plant production varies widely based on geographic location, number of production wells and the number of fields per plant, however, on average the majority of plants consist of one $25 \mathrm{MW}_{\mathrm{e}}$ production field (6). Complexes consist of multiple power plants tied together as one large power generation system. The largest and oldest geothermal complex in the U.S. is The Geysers, located on 45 square miles across two counties in California (7). The Geysers includes 327 production wells across 14 plants and had an average of $666.2 \mathrm{MW}_{\mathrm{e}}$ output in 2014 delivering 5,836,316 MWh of energy (7). The total potential power capacity of The Geysers is estimated to be approximately $1.4 \mathrm{GW}_{\mathrm{e}}(6)$ which means the facility is taking advantage of less than $50 \%$ the reservoir's capacity. This estimate is based on calculations using the Monte Carlo method of determining heat-in-place and may vary based on the accuracy of the input data. For example, plants such as the Steamboat Hills \& Springs in Nevada had a potential power capacity estimate of $63 \mathrm{MW}_{\mathrm{e}}(6)$ but the installed plant capacity is $148 \mathrm{MW}_{\mathrm{e}}(8)$ proving that actual capacity can exceed estimated potential reservoir power estimates.

\section{State Production}

The majority of the geothermal plants in the United States are located in the Western states near plate tonic activity (9). The most prominent states producing geothermal energy are California, Nevada, Utah and Hawaii, with other new developments and explorations in Alaska, Idaho, New Mexico, Oregon, and Wyoming as shown in Table 1 (8). California alone produces 2,719 $\mathrm{MW}_{\mathrm{e}}$ of geothermal power totaling approximately $4.4 \%$ of the state's total energy production at 13,023 $\mathrm{GWh} / \mathrm{y}(8)$. Nevada is the second largest producer of geothermal power with output of $576 \mathrm{MW}_{\mathrm{e}}$ followed by Utah at $73 \mathrm{MW}_{\mathrm{e}}$ and Hawaii at $38 \mathrm{MW}_{\mathrm{e}}(8)$. The potential resources that are yet untapped are approximately 50\% in California and 60\% in Nevada and Utah (8).

TABLE 1 Geothermal Capacity by State

\begin{tabular}{|l|l|}
\hline State & $\begin{array}{l}\text { Installed Geothermal } \\
\text { Capacity }\end{array}$ \\
\hline California & $2,719 \mathrm{MW}_{\mathrm{e}}$ \\
\hline Nevada & $576 \mathrm{MW}_{\mathrm{e}}$ \\
\hline Utah & $73 \mathrm{MW}_{\mathrm{e}}$ \\
\hline Hawaii & $38 \mathrm{MW}_{\mathrm{e}}$ \\
\hline Oregon & $24 \mathrm{MW}_{\mathrm{e}}$ \\
\hline Idaho & $16 \mathrm{MW}_{\mathrm{e}}$ \\
\hline New Mexico & $4 \mathrm{MW}_{\mathrm{e}}$ \\
\hline Alaska & $0.7 \mathrm{MW}_{\mathrm{e}}$ \\
\hline
\end{tabular}




\begin{tabular}{|l|l|}
\hline Wyoming & $0.25 \mathrm{MW}_{\mathrm{e}}$ \\
\hline USA & $\mathbf{3 , 4 5 0} \mathbf{M W}_{\mathbf{e}}$ \\
\hline
\end{tabular}

\section{Country Production}

The United States currently has geothermal power production facilities capable of producing a total of 3,450 $\mathrm{MW}_{\mathrm{e}}$ of geothermal power, more than any other country (Table 1). In 2014 the US operated at an average output of 2,542 $\mathrm{MW}_{\mathrm{e}}$ producing 16,600 GWh over the year (8).

California's geothermal power production represents $78.8 \%$ of all geothermal power in the United States (8). While these power production numbers seem impressive when compared to the next largest producing countries, such as the Philippines at 1,870 MWe or Indonesia at 1,340 $\mathrm{MW}_{\mathrm{e}}$, it is dismal when compared to the total US energy demand, meeting only $0.48 \%$ as shown in Table 2 (8). In comparison, Iceland produces $665 \mathrm{MW}_{\mathrm{e}}$ of geothermal power which represents $29 \%$ of the country's total energy needs. Other countries such as New Zealand and Philippines get approximately $15 \%$ of their energy from geothermal power plants. While geothermal energy production continues to rise in most other countries, it is actually declining in the US due to policy barriers, inadequate transmission infrastructure, low natural gas prices and weak demand for new renewable geothermal power projects (6). The US Geological Survey estimates potential known resources in the US would generate 16,457 $\mathrm{MW}_{\mathrm{e}}$ of power, with an estimated 73,286 $\mathrm{MW}_{\mathrm{e}}$ of resources yet to be discovered (9).

TABLE 2 Geothermal Capacity by Country

\begin{tabular}{|l|l|l|}
\hline \multicolumn{1}{|c|}{ Country } & $\begin{array}{l}\text { Installed Geothermal } \\
\text { Capacity }\end{array}$ & $\begin{array}{l}\text { \% of Country's Total } \\
\text { Energy Production }\end{array}$ \\
\hline United States & $3,450 \mathrm{MW}_{\mathrm{e}}$ & $0.45 \%$ \\
\hline Philippines & $1,870 \mathrm{MW}_{\mathrm{e}}$ & $14 \%$ \\
\hline Indonesia & $1,340 \mathrm{MW}_{\mathrm{e}}$ & $1.1 \%$ \\
\hline Mexico & $1,017 \mathrm{MW}_{\mathrm{e}}$ & $2.4 \%$ \\
\hline New Zealand & $1,005 \mathrm{MW}_{\mathrm{e}}$ & $16 \%$ \\
\hline Italy & $916 \mathrm{MW}_{\mathrm{e}}$ & $2.1 \%$ \\
\hline Iceland & $665 \mathrm{MW}_{\mathrm{e}}$ & $29 \%$ \\
\hline Kenya & $594 \mathrm{MW}_{\mathrm{e}}$ & $25.9 \%$ \\
\hline Japan & $519 \mathrm{MW}_{\mathrm{e}}$ & $0.25 \%$ \\
\hline Turkey & $397 \mathrm{MW}_{\mathrm{e}}$ & $0.83 \%$ \\
\hline World Total & $\mathbf{1 2 , 6 3 5} \mathbf{M W}_{\mathbf{e}}$ & $(\mathrm{NA})$ \\
\hline
\end{tabular}

\section{World Production}

Total geothermal energy power production capacity worldwide today is in excess of 12,635 $\mathrm{MW}_{\mathrm{e}}$

(Table 2) delivering 73,549 GWh of energy (8). Estimates anticipate this number to increase to 21,443 $\mathrm{MW}_{\mathrm{e}}$ by the year 2020 (8). The total resources under development are over 30,000 $\mathrm{MW}_{\mathrm{e}}$ (6), however geothermal projects can take upwards of 7 years to complete (6), so all of this will not be realized by 2020. Communities and governments around the world have only tapped $6.5 \%$ of the total global potential for geothermal power based on current geologic knowledge and technology (6). Undeveloped resources Indonesia is the country holding the highest percentage of known geothermal resources, estimated at $28 \mathrm{GW}_{\mathrm{e}}$, or $40 \%$ of the world total; of this, about 
$5 \%$ has been developed (9). The geothermal market continues to grow at a sustained rate of 5\% with over 700 geothermal projects underway in 76 countries (6).

\section{CAN GEOTHERMAL ENERGY PRODUCE ENOUGH POWER FOR A WHOLE TOWN, CITY, OR COUNTRY?}

The majority of large scale geothermal production is comprised of traditional hydrothermal technology, where water is pumped into permeable rock reservoirs deep below the earth, is heated by the earth's core temperature, and is extracted to produce steam and generate electricity. A new developing technology called Enhanced Geothermal Systems (EGS) is similar, however, naturally occurring porous rock formations are not required. Instead, water is pumped at high pressures to create a fracture network in the non-permeable rock allowing water to flow through and become heated for steam production. If this technology proves to be successful, it will widely expand our ability to produce geothermal power. Both technologies are further discussed below along with factors that affect capacity.

\section{Hydrothermal}

If the full economic potential of geothermal resources can be realized, it would represent an enormous source of electricity production capacity. In 2012, the U.S. National Renewable Energy Laboratory (NREL) found that conventional geothermal sources (hydrothermal) in 13 states (Alaska, Arizona, California, Colorado, Hawaii, Idaho, Montana, Nevada, New Mexico, Oregon, Utah, and Washington) have a potential capacity of 38,000 $\mathrm{MW}_{\mathrm{e}}$, which could produce 308 million MWh (1,050 trillion BTU) of electricity annually (10). The United States consumes approximately 1,588 trillion BTU in coal energy production per year, so geothermal would meet over $65 \%$ of this demand (11).

\section{Enhanced Geothermal Systems (EGS)}

Enhanced Geothermal Systems (EGS) technologies keep improving and are becoming more competitive, and even more of the largely untapped geothermal resource could be mined. The NREL study found that hot dry rock resources could provide approximately another 4 million $\mathrm{MW}_{\mathrm{e}}$ of capacity (10). This is equivalent to more than all of today's United States electricity needs (11).

\section{Capacity Factors}

Geothermal energy can also provide continuous baseload electricity. The capacity factors of geothermal plants are comparable with those of coal and natural gas as seen in Figure 3 (12). With the combination of both the size of the resource base and its consistency, geothermal can definitely power a whole city, potentially a State and could power a small country and at one point the whole world.

Several factors such as the resources location, the temperature depths could decrease or eliminate this potential for some areas. If the resources are in protected lands such as National Parks or in developed areas, they will not be accessible. Furthermore, if access to required temperatures are too deep in a certain area, geothermal energy would not be feasible (13). Figure 3 presents capacity factors by source. 


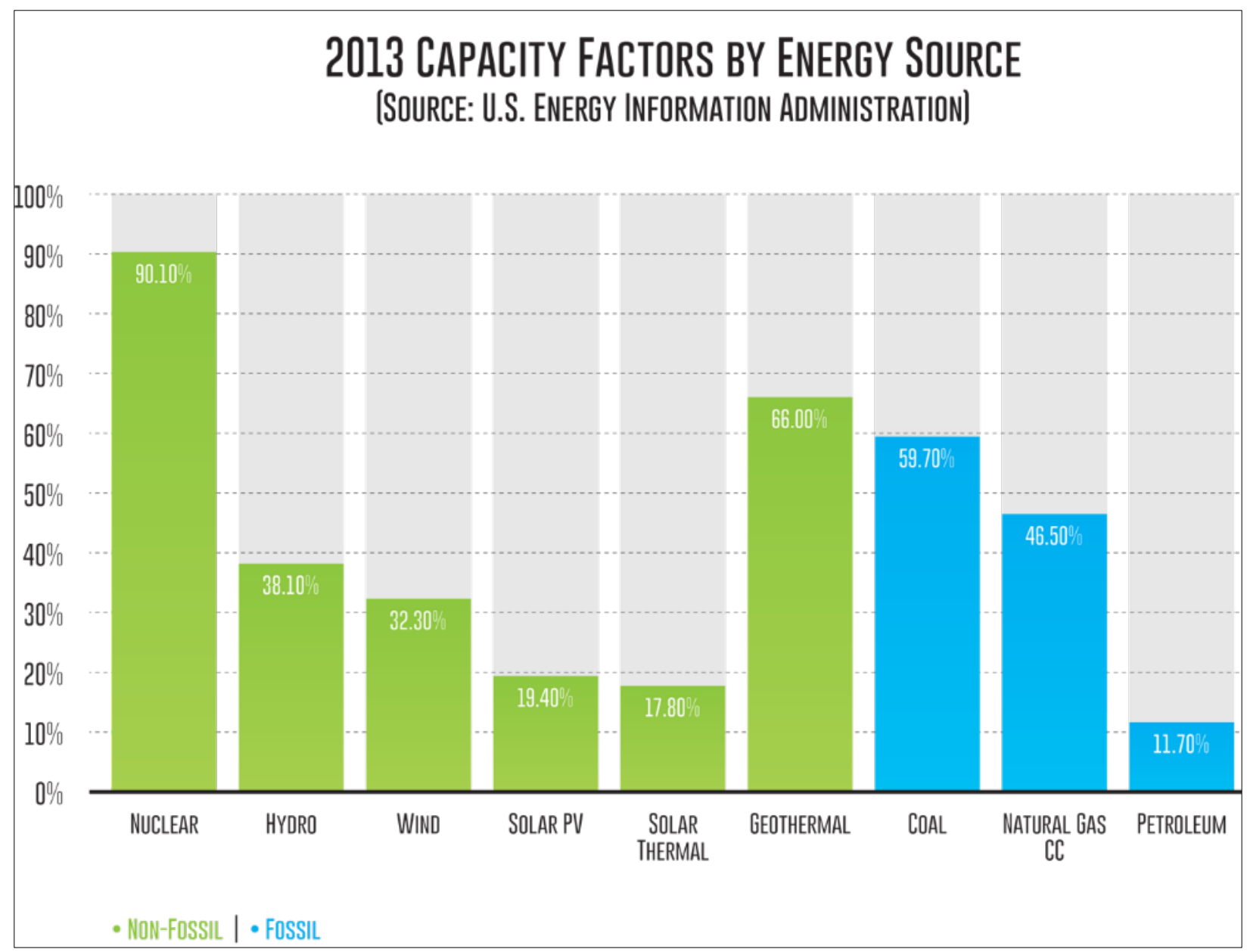

\section{FIGURE 3 Capacity factors by energy source.}

\section{Case Study: Miravalles Project, Costa Rica}

Central America is located along the geologically active region bordering the Pacific Ocean known as the "Ring of Fire", because of this, Central America is the source of many high grade hydrothermal areas. A study conducted in January and February 1999 by the Geothermal Energy Association, in conjunction with the U.S. Department of Energy, highlights the vast, untapped potential for geothermal power in Central America as demand for electricity grows. One example of a successful geothermal power project is Miravalles Hydrothermal Plant in Costa Rica. The Miravalles project is providing over $115 \mathrm{MW}_{\mathrm{e}}$ of steady, clean power to Costa Rica.

There were several challenges that this project had to overcome to become successful:

1. Environmental: There were concerns over water quality being affected by pumping hot mineralized water from the deep reservoir since there are many sensitive waterways and aquifers in close proximity to the plant. The issue has been addressed through reinjection of the process water back into the deep reservoir from which it came. In this way, the production-reinjection loop occurs only through the deep reservoir and in the plant itself, bypassing the surface waterways and aquifers entirely. 
2. Technology and Cost: Capital costs for a geothermal exploration program can be high if there is uncertainty as to the viability of the resource. Miravalles has proven to be an excellent and reliable producer overall, and there is already much data on the geothermal "hot spots" in Central America in general. Overall exploration technology prices have also come down and will most likely continue to go down (14).

\section{WHAT IS THE INITIAL COST AND LIFECYCLE COST OF GEOTHERMAL ENERGY?}

In order to use geothermal energy on a larger scale it is important to know if it is cost effective. Even though, geothermal energy is clean and sustainable, cost is a crucial factor in order to decide if it is worth using compared to other sources of energy. The question that arises is how the initial cost and lifecycle cost of geothermal energy compares to the other sources of energy and also how does the price for the consumer compares with the other sources.

\section{Initial Cost: Is it a good investment?}

Many studies have been made to address this matter and the results show that the initial construction cost for a geothermal facility represents two thirds of its lifecycle cost. Comparatively, the initial construction cost of a natural gas facility is only one third of its lifecycle cost, thereby making geothermal almost twice as costly and slightly harder to invest in this type of energy (15). However, despite the initial cost of geothermal power facilities being higher than that of comparable natural gas facilities, in the long run the total cost is similar over time (15). The results of these studies have shown that energy produced by natural gas and geothermal energy is very comparable over a long period of time (15). This shows that if investments are made towards geothermal energy the cost will be the same in the long run. Therefore clean and sustainable geothermal energy can be provided at the same cost of other energy sources with much less impact on the environment.

\section{Factors Influencing Cost}

There are quite a few factors that influence the cost of geothermal power plants (16). In order to build a geothermal power plant a specific site is needed (15). Early expenses are the majority of the total expense needed to build a power plant (15). The first activities that occur when building a power plant are the construction of the pipeline and well drilling (16). Constructing a pipeline can be costly, which is why other energy sources are more attractive, such as natural gas and existing pipelines (16). The cost depends on the size of the plant and land required to support the facility. In order for a developer to fully explore a geothermal resource he/she is required to lease or buy 2,000 acres of land or more (15). According to the energy.gov website, "A good site for geothermal development is considered one with hot geothermal fluid with low mineral and gas content, shallow qualifiers for producing and reinjecting the fluid and location preferably on private land to simplify permitting, proximity to existing transmission lines or load and availability of make-up water for evaporative cooling” (16). Other factors include cost of steel, other materials, and labor (15). Although these costs are universal to the power industry, in constructing a geothermal power plant they could be higher due to lack of existing infrastructure for this type of energy. Another important cost to consider is the cost of delivering the energy produced to the consumer. The initial cost for the field and power plant averages around \$2,500 per installed $\mathrm{kW}_{\mathrm{e}}$ in the United States (16). Operation and maintenance costs range from $\$ 0.01$ to $\$ 0.03$ per $\mathrm{kWh}(16)$. Most geothermal power plants can run greater than 
$90 \%$ availability, which means producing power more than $90 \%$ of the time. However, running this high can increase maintenance costs and result in higher priced electricity (16). Most of the time, initial investments are in other sources of energy, which means switching to geothermal could be very costly to the consumer and the provider.

For example, consider the comparison of the lifecycle costs of a small scale geothermal heat-pump versus the cost of conventional heat-pump for a typical 2,500 square-foot home that has a heating load of 60,000 BTU and cooling load of 60,000 BTU (17). In order to install a geothermal heat-pump system, it will cost $\$ 20,000$ to $\$ 25,000$ dollars, or around double the amount of money needed for conventional heating, cooling, and hot water systems (17). However, by using geothermal energy, utility bills can be reduced by $40 \%$ to $60 \%$. A very common way to save someone money of the upfront cost is financing this systems (17). Monthly payments can be very reasonable and save the homeowner money as soon as the system is installed (17). If a homeowner decided to switch to geothermal energy, the payback period can range from 2-10 years while the lifetime of a system can be 18-23 years which almost double the lifetime of a conventional system (17). Considering all the benefits of geothermal energy compared to the other types of energy, it might be wise to switch to geothermal even at a small scale, although it can be costly at first.

\section{ARE THERE LIMITATIONS IN REGARDS TO GEOGRAPHIC LOCATIONS?}

An important consideration with geothermal energy and any other renewable source of energy is availability at a reasonable cost. To achieve this, ideal locations for geothermal energy production are at locations where high temperature geothermal resources are available close to the earth's surface. Obviously, with this being said, not all locations are suitable for large scale geothermal power plants. However, the development of binary cycle power plants and improvements to drilling and extraction technology has allowed geothermal applications over a much greater geographical area.

Geothermal power plants have been traditionally built on the edges of tectonic plates where there are underground rocks with high thermal gradients. These permeable rocks allow the flow of fluids which make them ideal for geothermal power production. In addition, locations near to volcanic activity, geysers, and hot water springs typically have geothermal potential (18). However, there are locations with geothermal resources that show no indicators at the earth's surface. These are known as "blind locations". Modern day thermal, electric, and magnetic imaging are some methods used to search for geothermal energy sources. Drilling a well and testing the temperature deep underground is the most reliable method for locating a geothermal reservoir. This method of trial and error is costly and is partly responsible for the high initial costs of geothermal energy (18). In the United States most of the geothermal resources are located in the western states and Hawaii (18) as shown in Figure 4. 


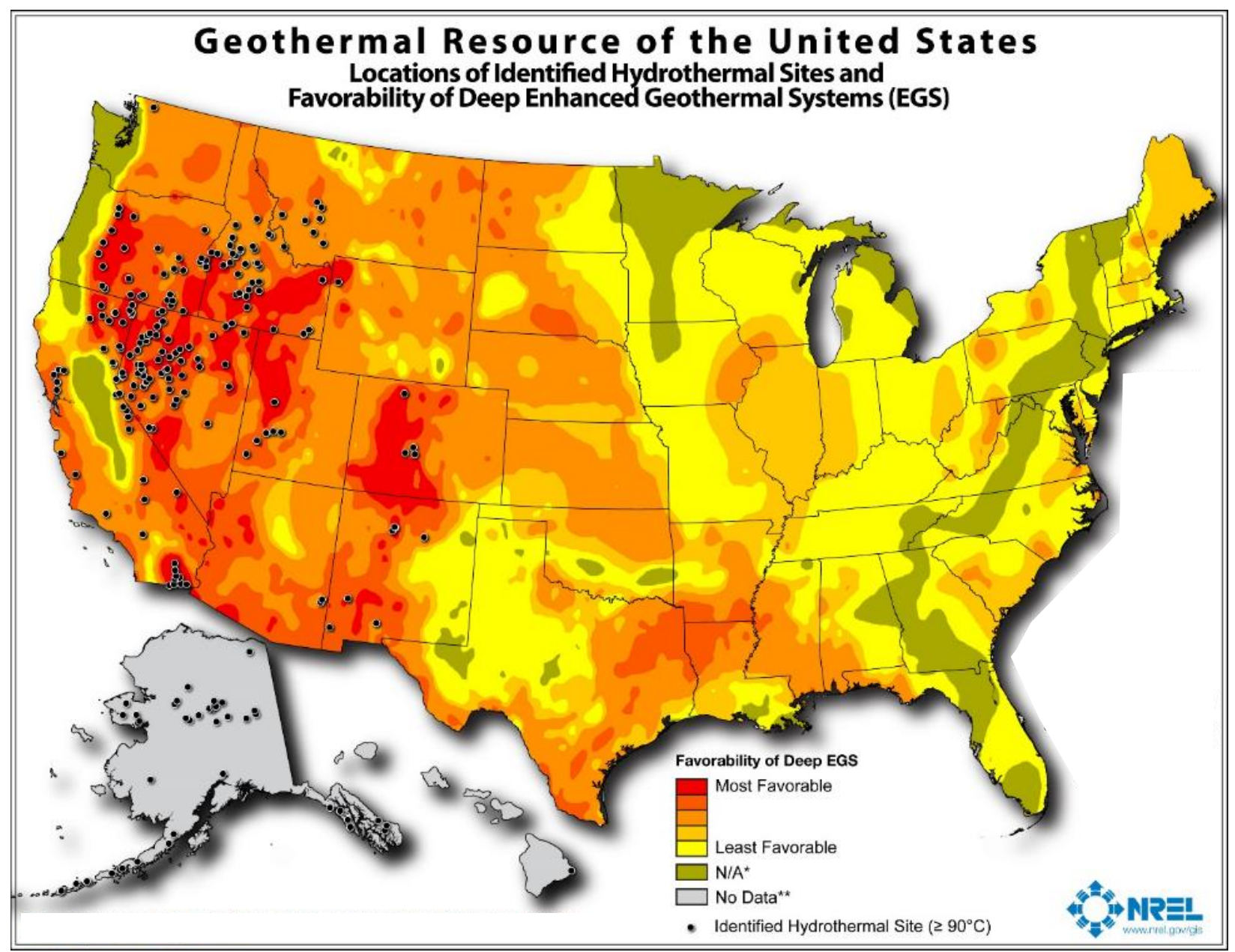

FIGURE 4 Geothermal resources of the United States.

The main producers of geothermal power globally are the United States, Philippines, Indonesia, Mexico, Italy, New Zealand, Iceland, and Japan (Table 2). Eighty five percent of the global geothermal energy production is generated by countries that lie within the "Ring of Fire" (18). The "Ring of Fire" is the geographical location along the rim of the Pacific Ocean that has high volcanic and seismic activity. Another location that shows promising geothermal potential is known as the "African Rift” and runs along the East coast of Africa. These geothermal locations can be seen in Figure 5 below. 


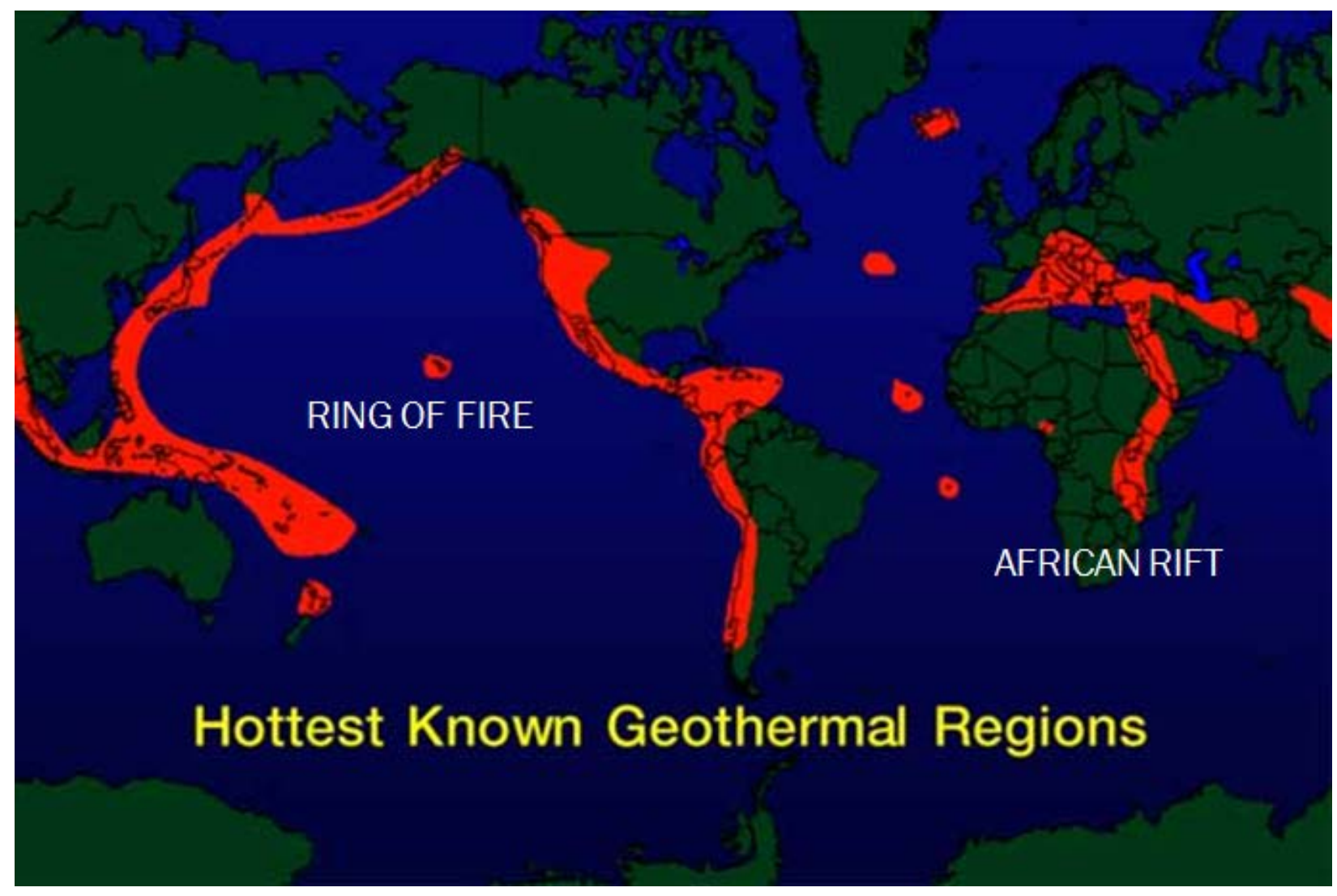

\section{FIGURE 5 Global geothermal regions (19).}

\section{ADVANTAGES OF GEOTHERMAL POWER OVER OTHER SOURCES OF RENEWABLE ENERGY.}

All renewable energies have their advantages and disadvantages. The locations where power is needed and how it will be used are key elements in determining what type of renewable energy should be implemented. Geothermal energy has some advantages of its own which can make it more attractive than other sources of renewable energy at times. For example, when compared to wind power, there may be larger visual and environmental impact than with geothermal energy. For example, a community may not find it attractive to have a wind farm next to the community where they live. Wind farms take up a significant amount of land, although, sometimes this is mitigated by using the land for agricultural purposes as well. Solar power plants require a significant amount of land as well. Wind turbines also generate noise, approximately 43 decibels (20), that may be seen as negative for some people. Geothermal energy plants do not generate noise. In addition, the geothermal system is contained underground, and the footprint of the aboveground equipment is relatively smaller than it would be for a wind farm or a solar power plant. Since the required land is not completely occupied by the power plant, the surrounding land can be utilized for agriculture. Additionally, wind power and solar power both have similar limitations. In a wind power system, if there is no wind, then energy cannot be generated, and in a solar power system, if it is cloudy then the same issue occurs (21). What this means is that these two sources of renewable energy cannot guarantee that they will always generate the required amount of energy. Different from these renewable energy sources, geothermal power can be produced as a base load renewable energy resource. This means that it operates 24 hours a 
day, 7 days a week regardless of changing weather, providing a uniquely reliable and continuous source of clean energy (22). Geothermal power can also be used as a secondary or hybrid system for other sources of renewable energy. For example, in the cases of wind and solar power where there may be intermittent periods that energy will not be produced. During these periods, geothermal energy can be utilized in two different ways. One option is to use a geothermal system as a supplement to produce energy during the periods that the other renewable energy system cannot. They can also be used as a hybrid system. As an example, when used as a hybrid with a solar power plant, geothermal energy allows for the power output from the hybrid power plant to increase by about $8 \%$ in comparison to the same standalone solar power system without the geothermal support (23). This can enhance the efficiency of the entire system while providing clean, reliable power. Another option is to use a geothermal system to store the excess energy produced so that it can later be used during the intermittent periods. Additionally, in comparison to wind power, with geothermal there is the possibility of exploiting geothermal water as a source of heat utilized in municipality heating systems. This is something that wind power plant could never offer (24).

\section{CONCLUSION}

The amount of geothermal power that can be produced can be estimated between 3 to $6.8 \mathrm{MW}_{\mathrm{e}}$ per well, or $25 \mathrm{MW}_{\text {e }}$ per plant, assuming the geothermal wells are located in the western part of the United States where plate tectonic activity is highest. This will vary based on geologic formation at the well field and will require exploratory well drilling to further quantify. As a whole, the United States remains the largest geothermal power producing country capable of generating up to 3,450 $\mathrm{MW}_{\mathrm{e}}$ with California contributing almost $80 \%$ of this total. This however, only represents less than $0.5 \%$ of our country's energy demand, which is well below other geothermal power producing countries such as Iceland and Kenya. Through the development of new EGS technologies, geothermal is able to meet the energy demand of the United States, the largest energy consumer the world.

Initial costs of geothermal power plants may high, even double compared to other power generation plants, due to the high cost of well drilling and well exploration. However, the lifecycle costs of geothermal plants tend to be much lower, resulting in a sound economic choice over the lifespan of a facility. When considering the environmental benefits of using geothermal power over traditional forms of power production, the high initial cost can be justified more easily.

Although geothermal energy may be limited to certain locations, geothermal power production can still be widely expanded in many portions of the United States. Geothermal power production continues to grow in the US and worldwide, and as we continue to develop new geothermal technologies, such as EGS, we will be able to take full advantage of the known potential resources available to us and continue to discover new resources.

Geothermal energy does have its advantages over other sources of renewable energy. Some of the major advantages identified were that it is available at all times, and that it can be used to support other renewable energy systems. Geothermal energy has a great potential to expand as a source of renewable energy and can be used all over the world.

In conclusion, geothermal has the potential to be the renewable energy of choice in many areas of the United States and world. Independent of what source of renewable energy is used, however, the implementation and use of renewable energy at a higher level is necessary in order to provide clean energy for future generations. 


\section{REFERENCES}

1. United States Environmental Protection Agency (EPA). Climate Change: Basic Information. http://www3.epa.gov/climatechange/basics/. Accessed Nov. 16, 2015.

2. National Renewable Energy Laboratory (NREL). Geothermal Energy Basics. http://www.nrel.gov/learning/re_geothermal.html. Accessed Nov. 16. 2015

3. The Geysers: Historic Timeline. Calpine Corporation, 2015. Retrieved from http://www.geysers.com/history.aspx.

4. Harding-Newman, T., J. Morrow, S. Sanyal. Success of Geothermal Wells: A Global Study. International Finance Corporation, Washington, DC, 2013.

5. Monastero, F. C. Model for Success: An Overview of Industry-Military Cooperation in the Development of Power Operations at the Coso Geothermal Field in Southern California. The Geothermal Resources Council (GRC) Bulletin. September/October 2002, Pp. 188-194.

6. Mateck, B. 2014 Annual U.S. \& Global Geothermal Power Production Report. Geothermal Energy Association, 2014.

7. Geysers by the Numbers: The Geysers Geothermal Field 2014 Statistics. Calpine Corporation, 2015. Retrieved from http://www.geysers.com/media/GeysersStatisticsFactSheetV4.pdf.

8. Bertanni, R. Geothermal Power Generation in the World: 2010-2014 Update Report. Proceedings World Geothermal Congress, Melbourne, Australia, 2015.

9. Blodget, L. Geothermal Basics. Geothermal Energy Association. http://geo-energy.org/geo_basics.aspx. Accessed on Nov. 6, 2015.

10. Lopez, Anthony, et al. U. S. Renewable Energy Technical Potentials: A GIS Based Analysis. Publication FHWA-RD-01-113. FHWA, National Renewable Energy Laboratory, 2012.

11. US Energy Information Administration. Table C4. Total End-Use Energy Consumption Estimates. http://www.eia.gov/state/seds/data.cfm. Accessed Nov. 4, 2015

12. National Renewable Energy Laboratory. Energy Technology Cost and Performance Data Energy Technology Cost and Performance Data. http://www.nrel.gov/analysis/tech_lcoe_re_cost_est.html. Accessed Nov. 4, 2015

13. The Future of Geothermal Energy: Impact of Enhanced Geothermal Systems (EGS) on the United States in the $21^{\text {st }}$ Century. Massachusetts Institute of Technology, 2006.

14. Kim, Ester. Geothermal Power in Central America: A Case Study of the Miravelle Project, Costa Rica. Massachusetts Institute of Technology, Apr. 4, 2001.

15. Geothermal Energy Association. Power Plant Costs. http://geo-energy.org/geo_basics_plant_cost.aspx. Accessed Nov. 10, 2015.

16. Office of Energy Efficiency \& Renewable Energy. Geothermal FAQS. http://energy.gov/eere/geothermal/geothermal-faqs\#geothermal_energy_cost. Accessed Nov. 10, 2015.

17. Renewable Technology. Costs. http://www.energyhomes.org/renewable\%20technology/geoinstallation.html. Accessed Nov. 10, 2015.

18. U.S. Energy Information Administration (EIA). Geothermal Explained, "Where Geothermal Energy is found”. http://www.eia.gov/energyexplained/index.cfm. Accessed Nov. 17, 2015.

19. Geothermal Energy Research Office - Malta (GEROM). Hottest known geothermal regions (figure). http://www.gerom.org/page.asp. Accessed Nov. 19, 2015.

20. General Electric Company (2015). How loud is a Wind Turbine? GE Response. http://www.gereports.com/post/92442325225/how-loud-is-a-wind-turbine/. Accessed Nov. 8, 2015.

21. GA Drilling. Renewable duel: Geothermal vs. Wind. https://geothermania.blogactiv.eu/geothermal_energy/ ultra_deep_drilling_technologies/renewable-duel-geothermal-vs-wind_2009_10_20/. Accessed Nov.10, 2015.

22. Geothermal Energy Association (GEA). Why Support Geothermal Energy? 2012. Retrieved from http://geoenergy.org/pdf/FINALforWEB_WhySupportGeothermal.pdf.

23. Turchi, C., Zhu, G., Wagner, M., Williams, R. and Wendt, D. Geothermal/Solar Hybrid Design: Use of Geothermal Energy for CSP Feedwater Heating. Idaho National Laboratory, Geothermal Resource Council 2014 Annual Meeting, Vol. 38, pp 817-823.

24. Massachusetts Institute of Technology (MIT). The Future of Geothermal Energy Impact of Enhanced Geothermal Systems (EGS) on the United States in the 21st Century. Idaho National Laboratory, 2006. Retrieved from http://geothermal.inel.gov and http://www1.eere.energy.gov/geothermal/egs_technology.html. 